University of Nebraska - Lincoln

DigitalCommons@University of Nebraska - Lincoln

Faculty Publications, UNL Libraries

Libraries at University of Nebraska-Lincoln

2012

\title{
The Ogallala Aquifer in Nebraska: Gray Literature (1891-2010)
}

\author{
Adonna Fleming \\ University of Nebraska-Lincoln, dfleming2@unl.edu \\ Leslie M. Delserone \\ University of Nebraska-Lincoln, Idelserone2@unl.edu \\ Elaine Maytag Nowick \\ University of Nebraska-Lincoln, enowick@unl.edu
}

Follow this and additional works at: https://digitalcommons.unl.edu/libraryscience

Part of the Library and Information Science Commons

Fleming, Adonna; Delserone, Leslie M.; and Nowick, Elaine Maytag, "The Ogallala Aquifer in Nebraska: Gray Literature (1891-2010)" (2012). Faculty Publications, UNL Libraries. 275.

https://digitalcommons.unl.edu/libraryscience/275

This Article is brought to you for free and open access by the Libraries at University of Nebraska-Lincoln at DigitalCommons@University of Nebraska - Lincoln. It has been accepted for inclusion in Faculty Publications, UNL Libraries by an authorized administrator of DigitalCommons@University of Nebraska - Lincoln. 
Published in Journal of Agricultural \& Food Information 13 (2012), pp. 213-239;

doi: 10.1080/10496505.2012.692238

Copyright (C) 2012 Taylor \& Francis Group, LLC. Used by permission.

Submitted December 15, 2011; accepted February 8, 2012.

\title{
The Ogallala Aquifer in Nebraska: Gray Literature (1891-2010)
}

\author{
Adonna Fleming, Leslie M. Delserone, and Elaine Nowick \\ University of Nebraska-Lincoln Libraries, Lincoln, Nebraska, USA \\ Corresponding author - Adonna Fleming, Geology Library, 10 Bessey Hall, University of \\ Nebraska-Lincoln, Lincoln, NE 68588-0344, USA; email afleming@unlnotes.unl.edu
}

\begin{abstract}
The Ogallala Aquifer is a key water resource for several U. S. states. TransCanada, a Canadian company, proposes to construct the Keystone XL pipeline to transport tar sands crude oil from Alberta to refineries in Texas; one proposed route would bury the pipeline in the Aquifer, raising water quality and environmental concerns. A rich inventory of information about the Aquifer predates the current controversy. This article presents a key subset of an extensive, ongoing bibliography: 128 citations to gray literature about the Ogallala Aquifer in Nebraska, which are inaccessible online and/or held in only a few libraries. The authors present several examples to illustrate the relevance of this gray literature to current events, comment on difficulties encountered during the bibliographic harvest and the identification of this subset, and reiterate the need for planned preservation through digitization of historical (print) gray literature.
\end{abstract}

Keywords: gray literature, grey literature, Keystone XL pipeline, Nebraska, Ogallala Aquifer

\section{Background}

TransCanada's proposed construction of the Keystone XL pipeline, to transport tar sands crude oil from Alberta to refineries in Texas, raises multiple environmental concerns. Opponents decry the environmental damage from extraction processes, construction of the pipeline, and potential pipeline leaks. For many citizens in Nebraska, the pipeline's proposed placement in the ecologically unique 
Sandhills region and through the Ogallala Aquifer, makes these more global concerns local. The Ogallala Aquifer is a vast water resource underlying Nebraska and seven other states (South Dakota, Wyoming, Colorado, Kansas, Oklahoma, New Mexico, and Texas). It contains over 3 billion-acre feet of water, with $65 \%$ of its volume in Nebraska (Kromm \& White, 1992).

\section{The Ogallala Aquifer}

The Aquifer's formation began 70 to 50 million years ago during the Laramide orogeny, when tectonic plate movement along the western margin of North America created uplift, forming the present day Rocky Mountains. Water from mountain streams and glaciers transferred vast sediments southeastward. These permeable sediments, 500 feet thick in places, overlay impermeable bedrock, causing the water to collect in a vast underground reservoir (Bittinger \& Green, 1980). About 10,000 years ago, the last of the glaciers withdrew and contributing rivers diverted southward, leaving the Aquifer with little or no recharge (Opie, 2000). The controversial use of this nonrenewable resource began during the early days of European settlement and the prevailing theory of "rain follows crops," continuing with the recent proposal to build the TransCanada Keystone XL oil pipeline through the Aquifer (United States Department of State, 2011).

European immigrants pushing westward in the United States received encouragement and tangible support to settle and practice farming in the high plains, instead of passing through to land that was more desirable on the west coast. In 1862, the Homestead Act offered settlers 160 acres of free land if they stayed and farmed 5 years. In 1880 the popular slogan, used by land promoters, that "rain follows the plow" became "science" with the endorsement of Joseph Henry of the Smithsonian Institute, F. V. Hayden of the U. S. Geological Surveys of the Territories, and Nebraska scientist Samuel Aughey. In their pamphlet, Agriculture Beyond the 100th Meridian, Aughey and C. D. Wilber (1880) stated, "As pioneers take up the government lands, and encroach on the plains the line of abundant rainfall also marches westward" (p. 5). They attempted to validate their theory by citing the heavy rainfall that occurred during the decade of 1878 and 1887 (Opie, 2000). These beliefs and the accompanying agricultural practices led to disastrous results, culminating with the Dust Bowl of the 1930s (Opie, 2000). The farmers who remained turned to irrigation. At first, irrigators tapped surface water and shallow wells; as technology for deep drilling developed after World War II, they then utilized the Ogallala Aquifer.

Drought, low crop prices, and limited technology slowed the use of the Aquifer for irrigation in Nebraska. The 1950s saw an improvement in welldrilling technology, and the number of wells drilled for irrigation increased from 1,500 in 1941 to 8,000 in 1953 (Bleed, 1993). The number of wells drilled averaged about 2,000 a year in the 1950s and 1960s (Schafer, 1993). 
The mass production and use of center-pivot irrigation systems in the 1970s dramatically increased irrigation, especially in western Nebraska where the shape of the land prohibited gravity irrigation methods. The number of centerpivot systems increased from 2,725 in 1972 to more than 27,000 in 1988 (Sheffield, 1993). By 1990, center-pivot irrigation watered more than 3 million of the 8 million acres of crops produced in Nebraska (Evert, 1993). Today Nebraska has 118,843 wells for crop irrigation (Nebraska Department of Natural Resources, 2011), and over $85 \%$ of all irrigated land in the state uses groundwater (Schafer, 1993). Overall, the Ogallala Aquifer supports 14 million acres of crop production for the eight states it underlies, providing 5 trillion gallons of water annually. This crop production constitutes one-fifth of the total U.S. harvest (Ashworth, 2006).

\section{Gray Literature}

In a widely accepted definition, commercial publishers do not produce gray literature, which can include documents in both paper and electronic format produced by governments, academia, business, and industry (GreyNet International, 2011, para. 2). Studies of gray literature over the past decade indicate that it is expanding at a much higher rate than mainstream publishing (Coad, Hardicre, \& Devitt, 2006). The publication categories of gray literature vary by discipline, ranging from diaries and letters to conference proceedings, technical reports, unpublished dissertations and theses, newsletters, and digital scientific data sets (Auger, 1994; Ranger, 2005; Carroll, Crowe, \& Candlish, 2011). In water science, government documents make up the bulk of the gray literature (Contreras, 2000). While the Internet has made many federal government documents widely available through outlets such as the U.S. Geological Survey (USGS) Publications Warehouse, many local, state, and regional documents remain elusive. Couple these government documents with technical reports and dissertations and theses about the local watershed, and a researcher discovers that the gray literature contains a wealth of information useful in the study of the Ogallala Aquifer.

Completeness is another aspect of gray literature. Drafts, preliminary reports, and ongoing investigations often become widely available once published as a completed document. The question then becomes: Does the preliminary document have value? Yes, according to Charles Auger (1994); once these documents pass from "restricted and temporary" to "open and permanent," they become part of the footprint of the final document. Even after the final document becomes widely distributed through commercial means, the original remains in bibliographic indexes and is frequently cited (Auger, 1994). One can argue that this occurs because the draft or preliminary report contains information that is not available in the final report. For example, the Open File Report (OFR) is a 
series of preliminary research results published by the USGS frequently in cooperation with state geological surveys. The OFRs provide timely, "quick and dirty" releases of research data (Bichteler, 1991). A final, more refined report documents the completed research and supersedes earlier reports, but may be years in preparation. Many of the OFR entries contain detailed, large-scale maps that have more information than those in the final report. These preliminary documents may show project development over time and are valuable to historical and legal researchers, as well as to current participants in research groups with transitory membership.

Format is another attribute that classifies some information as gray literature. Social media has a huge influence on public opinion, yet the digital formats of blogs, twitters, emails, and webpages do not easily fit with traditional methods of bibliographic control. Earlier instances of social media communication included pamphlets and correspondence. In the late 1800s the controversy over settlement of the western plains peaked. Explorer, scientist, and Chief of the USGS, Army Major John W. Powell argued that the 160 acres allocated by the Homestead Act was not sustainable in the arid and semi-arid lands of the western plains. He advocated that it would take 2,560 acres to sustain any kind of farming, with most of the acreage in use as pasture and a small amount set aside for irrigated farming (Fite, 1966). Opposition arose from the numerous settlers moving into western Nebraska and the Dakotas as part of the "Great Dakota Land Boom." This drama played out through a series of pamphlets, speeches, and correspondence. Although these formats were major forms of communication, few found their way into the permanent bibliographic record. For example, in order to encourage pioneers to settle and farm the western plains, land promoters distributed the seven-page pamphlet Agriculture Beyond the 100th Meridian, printed in 1880 (Aughey \& Wilber, 1880). Only four U.S. libraries hold the pamphlet, written as a response to the 1878 Report on the Lands of the Arid Region of the United States, with a More Detailed Account of the Lands of Utah by John Wesley Powell. In contrast, more than 600 libraries have copies of Powell's report, reprinted several times since its original printing and distribution by the Federal Government.

\section{Objectives}

The harvest of citations to materials about the Ogallala Aquifer in Nebraska began in 2008 as a cooperative project with the Greater Western Library Association and the Western Waters Digital Library. Beyond the selected bibliographies found in books, research journal articles, and various scientific and technical reports, the authors identified only two other significant bibliographies that covered the Ogallala Aquifer. The most comprehensive, first published in 1998 and last updated in 2010, enumerates only federal and state government publications 
about the Aquifer. It does not cover any other types of gray literature, although it captures a citation to a state groundwater map dated 1964, and publications specifically about the Aquifer dating from 1980 (University of Nebraska at Kearney, 2011). The second, Ogallala Aquifer (1970-Aug 83), published in 1983, includes citations to publications for sale from the National Technical Information Service (NTIS), a division of the U.S. Department of Commerce (United States Department of Commerce, 1983). This bibliography lists 60 documents, with only 1, Quantitative Hydrogeology of the Upper Republican Natural Resources District Southwest Nebraska (Lappala, 1978), pertaining specifically to Nebraska. In order to provide a more comprehensive collection of resources, two of the authors (Adonna Fleming and Elaine Nowick) proposed the creation of an online bibliographic database of free, full-text resources. However, after evaluation of the harvested citations, the authors discovered that many of the documents, regardless of format, were either not widely available or were unavailable free of cost. The project's modified objectives became:

- to create and share a regularly updated, robust bibliography about the Ogallala Aquifer in Nebraska;

- to identify gray literature about the Aquifer, in order to increase awareness of these resources, and to explore the potential of making these more accessible via digitization.

\section{Methods}

The authors searched six bibliographic resources: Agricola, GeoRef, Water Resources Abstracts, WorldCat, the USGS Libraries Program (http://library. usgs.gov/), and the "Classic Catalog" of the University of Nebraska-Lincoln Libraries (http://libraries.unl.edu). The choice of resources reflected the authors' primary interest in scientific and technological research involving the Aquifer; environmental policy and water law were not priorities in these searches. The results were exported to RefWorks, a proprietary bibliographic citation management software.

Keywords searched were Ogallala (also variant Ogalala), aquifer, groundwater (also variants ground water, ground-water), irrigation, and water supply (also variant water-supply). Nebraska served as an additional limiter to these searches. Some of the initial 1,089 references addressed the Ogallala Aquifer in Nebraska and other states. The authors decided to concentrate on those citations that addressed only Nebraska in building the bibliography. The largest and deepest portion of the Ogallala Aquifer underlies Nebraska, covering 64,400 square miles (Guru \& Horne, 2000). The authors sorted the initial 1,089 references, selecting citations addressing only Nebraska, and then de-duplicated that selection, arriving at the current 758 records in the "Ogallala Masterfile" (as of October 2011). 
Readers with access to RefWorks may view this bibliography, which is a work in progress, at (http:/ / www.refworks.com/refshare2? site $=029901110171600000 /$ RWWEB107743349/Ogallala\%20Masterfile).

The subset of particular interest was the group of citations that appeared to be unavailable in a free full-text digital format or were not widely available within the United States. To develop this gray literature bibliography, the authors reviewed the 758 citations contained in the Ogallala Masterfile. As a first step, WorldCat title searches of the citations eliminated incomplete records and those duplicates that escaped the RefWorks de-duplication tool. The authors conducted title and/or author searches for the remaining 351 citations, via Google Scholar (http://scholar.google.com/), Nebraska's digitized state documents collection (http://nebraskaccess.ne.gov/), and the USGS Publications Warehouse. These searches verified that the references were (a) unavailable in full-text at no cost, or (b) not widely available in print or microform (available in five or fewer libraries in the United States), and (c) not out of scope of the bibliography. Those that were out of scope included primarily "how to" publications from the Nebraska Cooperative Extension Service, as well as titles (cataloged separately) from the series Nebraska Water Survey Papers and/or the federal Water Supply Papers. The gray literature discussed in this article is discoverable. Referring back to the definition of gray literature presented earlier, the authors' concern is primarily one of limited accessibility, because of non-digital format and/or limited copy availability. The remaining 128 citations to gray literature, arranged in chronological order, appear in the Appendix.

\section{Results and Discussion}

Approximately $17 \%$ of the 758 citations contained in the Ogallala Masterfile fell into the category of gray literature, as defined earlier. Graduate works, primarily master's theses from the University of Nebraska system, comprised the majority $(61 \%)$ of the gray literature collection (see Figure 1). Of the theses or dissertations, none were freely available online and, in most cases, the research was available only as a single print copy. The authors did not investigate whether any of this graduate research appeared subsequently in peerreviewed journals. However, it is likely that there is a unique level of detail found in the theses and dissertations, given that most scientific theses and dissertations are not publication-format and/or are unpublished in their entirety elsewhere. While doctoral dissertations are available digitally via ProQuest's Dissertations and Theses database, master's theses are not widely indexed in this resource, nor are these available in many institutional repositories (IRs). None of the Nebraska theses listed in the Appendix were available online via the University of Nebraska-Lincoln's (UNL) IR, Digital Commons. In the United States, authors of master's theses retain copyright, so digitization of this mate- 


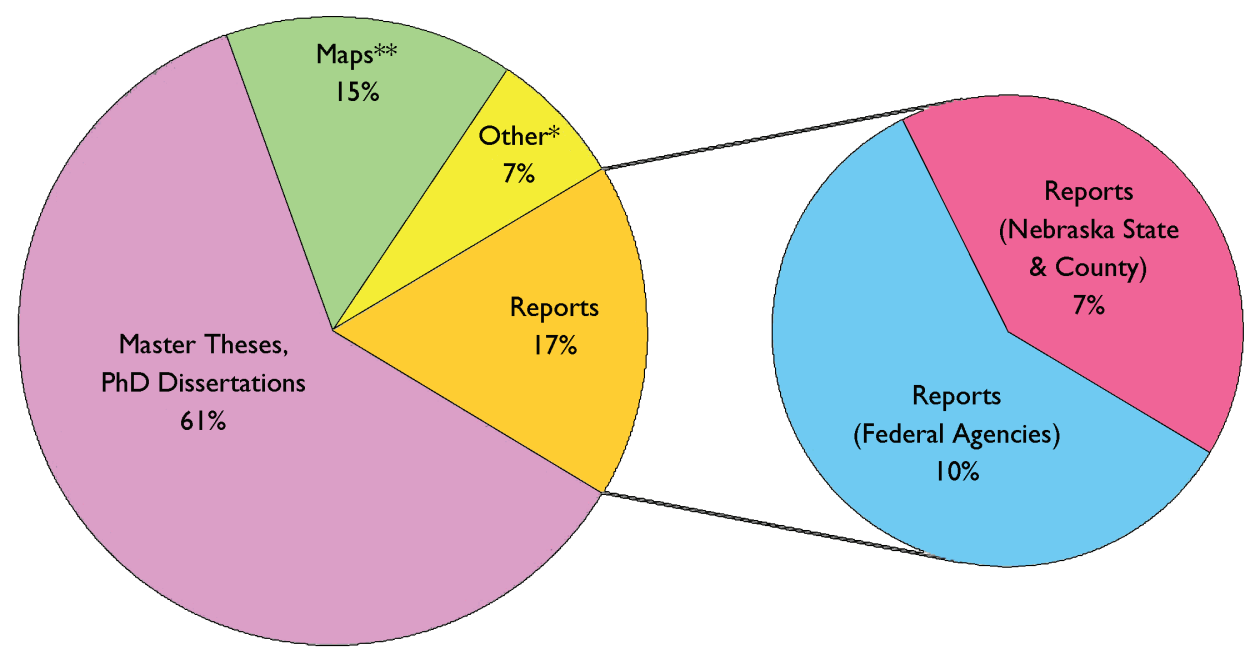

Figure 1. Gray Literature, Ogallala Aquifer in Nebraska, Categorized by Publication Type. * Contains Reports from Conference Proceedings, Private Papers, and the U.S. Army

** Primarily Published by the Nebraska Conservation and Survey Division

rial requires seeking out and receiving permission for digitization and public access to the work. As others note (Paillassard, Schopfel, \& Stock, 2007), universities should encourage or require studentresearchers to make their work available online in IRs or other appropriate digital libraries.

Of the remaining gray literature identified in this study, most are publications from the UNL Survey and Conservation Division and/or the USGS (Figure 1). There is no evidence that any of these publications are available digitally. As state and/or federal government publications, these documents are candidates for digitization and dissemination via the Digital Commons or another suitable repository. Notable exceptions include collections of field notebooks and other documentation (dating from 1891) from UNL's Survey and Conservation Division and a collection of archival records available only from a county office. After evaluation by an archivist, digitization, and provision of open online access, the use of these two archival sources would likely increase.

The distribution of publication types over the years reflects the increase in digital publication of government documents beginning in the late 1990s. Prior to 1996, the gray literature found in the Appendix is a mixture of state and federal documents and dissertations and theses. From 1997 on, the citations are predominantly to graduate research. Digital publication at the state and federal level increases the likelihood of discovery of and access to these items. However, the loss of born-digital government publications, with changes in administrations or appearance of new versions, is a serious concern if one accepts that superseded versions are part of the footprint of a document (Auger, 1994; Eells, 2007). 
Some might question the value of, or need to, access older reports, theses, or dissertations. A number of published accounts, written by information specialists and researchers representing a range of disciplines, support this need. Bichteler (1991) observes that geologists frequently consult state Open File Reports (OFRs), dissertations, and theses, because these provide regional information and data that are unique spatially and temporally. Without appropriate cataloging, not all available versions are discoverable; without the retention of earlier versions, accessibility to the state OFRs is limited or impossible. Print-only theses are inaccessible if unavailable digitally or via interlibrary loan. Colten (2005), a geography professor researching interstate pollution in the United States, details a difficult process to obtain a 1949 technical report issued by the U.S. Public Health Service. Unable to visit the library likely to house this document, since national security rules allow access only to federal employees, he discovered that the report was no longer available from the NTIS. Colten finally located a librarian willing to photocopy the report for him. He concludes: "Scholars who rely on historical documents must help librarians and archivists convince administrators of the importance of vital records ..." (Colten, 2005, p. 678). Costello (2007) describes efforts to capture the gray literature, including theses and dissertations, of Louisiana's deteriorating and disappearing coastal wetlands. This project involved the identification and selection of gray literature by the author, a librarian. She also discusses a survey of the users of this information, the results of which helped guide selection and prioritization in the project. Approximately $66 \%$ of the respondents considered theses and dissertations as "valuable" to their research, and $83 \%$ placed "state government reports" in the same category (Costello, 2007). Hurricane Katrina interrupted the development of the citation database and subsequent digitization of selected gray literature, a reminder that unexpected disasters also affect the availability of gray literature. Cordes (2004) reports on the impact of gray literature produced by GESAMP, the Joint Group of Experts on the Scientific Aspects of Marine Environmental Protection (http://www.gesamp.org/). Through citation analysis using ISI's Web of Science, she demonstrated a high level of use of many of GESAMP's publications. There was a relatively low rate of citation by GESAMP affiliates, indicating discovery and access by those outside the organization. Cordes concludes that "grey literature publications can be long-lived and influential, deserving of much more respect than is often accorded to the genre" (p. 67). The authors themselves experienced the value of access to gray literature. In attempting to confirm the quote attributed to Aughey and Wilber regarding rainfall, one of the authors discovered that Opie (2000) inaccurately reported it in his book, Ogallala: Water for a Dry Land. Access to a copy of Aughey and Wilber's 1880 pamphlet led to the discovery of the complete quotation.

The ongoing controversy about the placement of the Keystone XL pipeline, particularly in Nebraska, accentuates concern for the availability of comprehen- 
sive information about the Ogallala Aquifer. The authors examined the reference lists provided in the Keystone XL Pipeline Project: Final Environmental Impact Statement (EIS; United States Department of State, 2011), specifically for inclusion of any of the gray literature identified in this study. Many of the Nebraska-related citations are USGS publications. These include maps, Water Supply Papers, Fact Sheets, Circulars, and Professional Papers; most of these are available online via the USGS Publications Warehouse. Also cited are a number of reports available online from the Nebraska Games and Parks Commission; these do not relate to water resources directly, but address species considered threatened, endangered, or of conservation interest. The authors found no publications from UNL's Conservation and Survey Division in the review, despite the wide availability of many of these. In fact, the only water-related reference from UNL was Eastern Nebraska Water Resources Assessment (ENWRA; Joeckel, 2009), accessed online in July 2011. The EIS reference lists include none of the theses or dissertations listed in the Appendix; in fact, very few dissertations or theses from any institution are present in the reference lists. It is, of course, possible that the gray literature enumerated in this manuscript is irrelevant to the EIS. However, the omission from the EIS of many widely accessible and seemingly relevant entries from an extensive body of research about the Aquifer in Nebraska - as captured in the Ogallala Masterfile - is disturbing.

Another disturbing aspect of this project was the difficulty that three librarians experienced in determining whether items were available online, and where. The authors knew to look beyond Google Scholar in attempting to find these publications, realizing that repositories like the USGS Publications Warehouse and the Nebraska state documents collection exist. Where will less-experienced searchers look, and how much energy will they expend?

The authors also encountered difficulties during the bibliographic harvest: incomplete citations, items cataloged separately that were actually part of a series, and difficulties in clarifying holdings. The authors noted when searching a title in WorldCat that, in some cases, there would be more than one record for an item, often with a different number of holdings. The authors found they had to look at each listing to find the most complete record. For example, WorldCat lists the Bradley and Johnson 1957 publication, Geology and Ground-Water Hydrology of the Valleys of the Republican and Frenchman Rivers, Nebraska, three times, with holdings of 44,5 , and 1 , respectively. The one with the most number of holdings is the full catalog record, submitted by an OCLC member institution. The other two are abbreviated versions of cataloging acquired during batch loading from international libraries. After investigating all the entries, the authors did not include this title in the gray literature (Appendix), because it is widely held. However, they noted the frustration this could cause someone who was looking for a title and did not know how to recognize the different levels of cataloging or that the series title, Contributions to the Hydrology of the United States, 1955, included the monographic title: Geology and Ground-Water Hydrology 
of the Valleys of the Republican and Frenchman Rivers, Nebraska. Individual libraries determine whether or not to catalog to the monographic level in a series. The errors would multiply if one of the bibliographic indexes were to pick up the incomplete record and then have that cited in professional papers or used for interlibrary loan requests.

Different formats of an item also caused different results, in terms of availability. For example, the Federal Government distributes documents in both paper and microfiche, and the lending library decides which format to collect. This forces researchers to examine multiple records, for both paper and fiche, in order to accurately determine an item's availability.

\section{Conclusion}

This study enumerates citations to gray literature that directly addresses scientific and technological research about the Ogallala Aquifer in Nebraska, a subset of a larger, ongoing bibliography available at this time to readers with access to RefWorks. The work reveals difficulties in harvesting complete citations, in many cases, and in identifying online access points for other documents. Our water resources are critical for human and environmental health, crop and animal production, and U.S. national security. The preservation and increased ease of access to research about the Ogallala Aquifer should be part of knowledge and records management for the governments of at least the eight states that enjoy the Aquifer's bounty, if not part of a national plan. The authors join with other researchers, librarians, archivists, and citizens to add evidence to the need for a preservation plan for key gray literature, as well as a plan to make these publications more accessible through digitization. The increased awareness and ease of access to gray literature will support more fully informed and robust research, public policy, and planning (e.g., oil pipeline placement).

\section{References}

Ashworth, W. (2006). Ogallala blue: Water and life on the high plains. New York, NY: Norton. Auger, C. P. (1994). Information sources in grey literature. London, United Kingdom: Bowker. Aughey, S., \& Wilber, C. D. (1880). Agriculture beyond the 100th meridian. Lincoln, NE: University of Nebraska-Lincoln.

Bichteler, J. (1991). Geologists and gray literature: Access, use, and problems. Science and Technology Libraries, 11, 39-50.

Bittinger, M. W., \& Green, E. B. (1980). You never miss the water till ... (the Ogallala story). Littleton, CO: Water Resources.

Bleed, A. S. (1993). Climate and hydrology. In C. A. Flowerday (Ed.), Flat water: A history of Nebraska and its water (pp. 45-62). Lincoln: University of Nebraska-Lincoln, Conservation and Survey Division, Institute of Agriculture and Natural Resources. 
Bradley, E., \& Johnson, C. R. (1957). Geology and ground-water hydrology of the valleys of the Republican and Frenchman Rivers, Nebraska. Washington, DC: U.S. Government Printing Office.

Carroll, B. C., Crowe, J., \& Candlish, J. R. (2011). Scientific data: Increasing transparency and reducing the grey. TGJ (The Grey Journal), 7(1), 33-39.

Coad, J., Hardicre, J., \& Devitt, P. (2006). How to search for and use "grey literature" in research. Nursing Times, 102(50), 35-36.

Colten, C. E. (2005). Gray literature and other endangered documents. Environmental History, 10, 677-678.

Contreras, N. (2000). Efficient management of water resources: An analysis of grey literature for the new millennium. Atizapan de Zaragoza, Mexico: Third World Centre for Water Management.

Cordes, R. (2004). Is grey literature ever used? Using citation analysis to measure the impact of GESAMP, an international marine scientific advisory board. The Canadian Journal of Information and Library Science, 28(1), 49-69.

Costello, G. R. (2007). Louisiana coastal wetlands and Louisiana coastal grey literature: Vanishing treasures. TGJ (The Grey Journal), 3(3), 146-153.

Eells, L. (2007). Born-digital agricultural resources: Archives and issues. Quarterly Bulletin of the International Association of Agricultural Information Specialists, 52(3-4), 67-82.

Evert, C. (1993). Industry. In C. A. Flowerday (Ed.), Flat water: A history of Nebraska and its water (pp. 71-81). Lincoln: University of Nebraska-Lincoln, Conservation and Survey Division, Institute of Agriculture and Natural Resources.

Fite, G. C. (1966). The farmers' frontier 1865-1900. New York, NY: Holt.

GreyNet International. (2011). Retrieved from http://www.greynet.org

Guru, M. V., \& Horne, J. E. (2000). The Ogallala Aquifer. Poteau, OK: The Kerr Center for Sustainable Agriculture.

Joeckel, R. M. (2009). Eastern Nebraska Water Resources Assessment (ENWRA). Retrieved from http://www.enwra.org/media/enwra_overview.pdf

Kromm, D. E., \& White, S. E. (1992). Groundwater exploitation in the high plains. Lawrence: University Press of Kansas.

Lappala, E. G. (1978). Quantitative hydrogeology of the Upper Republican Natural Resources District, Southwest Nebraska. Lincoln, NE: U.S. Geological Survey, Water Resources Division.

Nebraska Department of Natural Resources. (2011). Summary report, registered groundwater wells by county. Retrieved from http://dnrdata.dnr.ne.gov/wellscs/Menu.aspx

Opie, J. (2000). Ogallala: Water for a dry land (2nd ed.). Lincoln: University of Nebraska Press.

Paillassard, P., Schopfel, J., \& Stock, C. (2007). Dissemination and preservation of French print and electronic theses. TGJ (The Grey Journal), 3(2), 77-93.

Powell, J. W. (1878). Report on the lands of the arid region of the United States, with a more detailed account of the lands of Utah. Washington, DC: Government Printing Office.

Ranger, S. L. (2005). Grey literature in special libraries: Access and use. Publishing Research Quarterly, 21(1), 53-63. 
Schafer, S. (1993). Economics and finance. In C. A. Flowerday (Ed.), Flat water: A history of Nebraska and its water (pp. 113-131). Lincoln: University of Nebraska-Lincoln, Conservation and Survey Division, Institute of Agriculture and Natural Resources.

Sheffield, L. F. (1993). Technology. In C. A. Flowerday (Ed.), Flat water: A history of Nebraska and its water (pp. 87-106). Lincoln: University of Nebraska-Lincoln, Conservation and Survey Division, Institute of Agriculture and Natural Resources.

United States Department of Commerce, National Technical Information Service. (1983). Ogallala Aquifer: 1970-Aug 83: Citations from the NTIS database. Springfield, VA: Author.

United States Department of State. (2011). Keystone XL Pipeline Project: Final environmental impact statement. Retrieved from http://keystonepipeline-xl.state.gov/documents/ organization/181184.pdf

University of Nebraska at Kearney. (2011). Nebraska ecosystems, geology, ground and surface water, Ogallala Aquifer, and water quality: A bibliography of government documents. Retrieved from http://www.unk.edu/academics/library.aspx?id=14421 


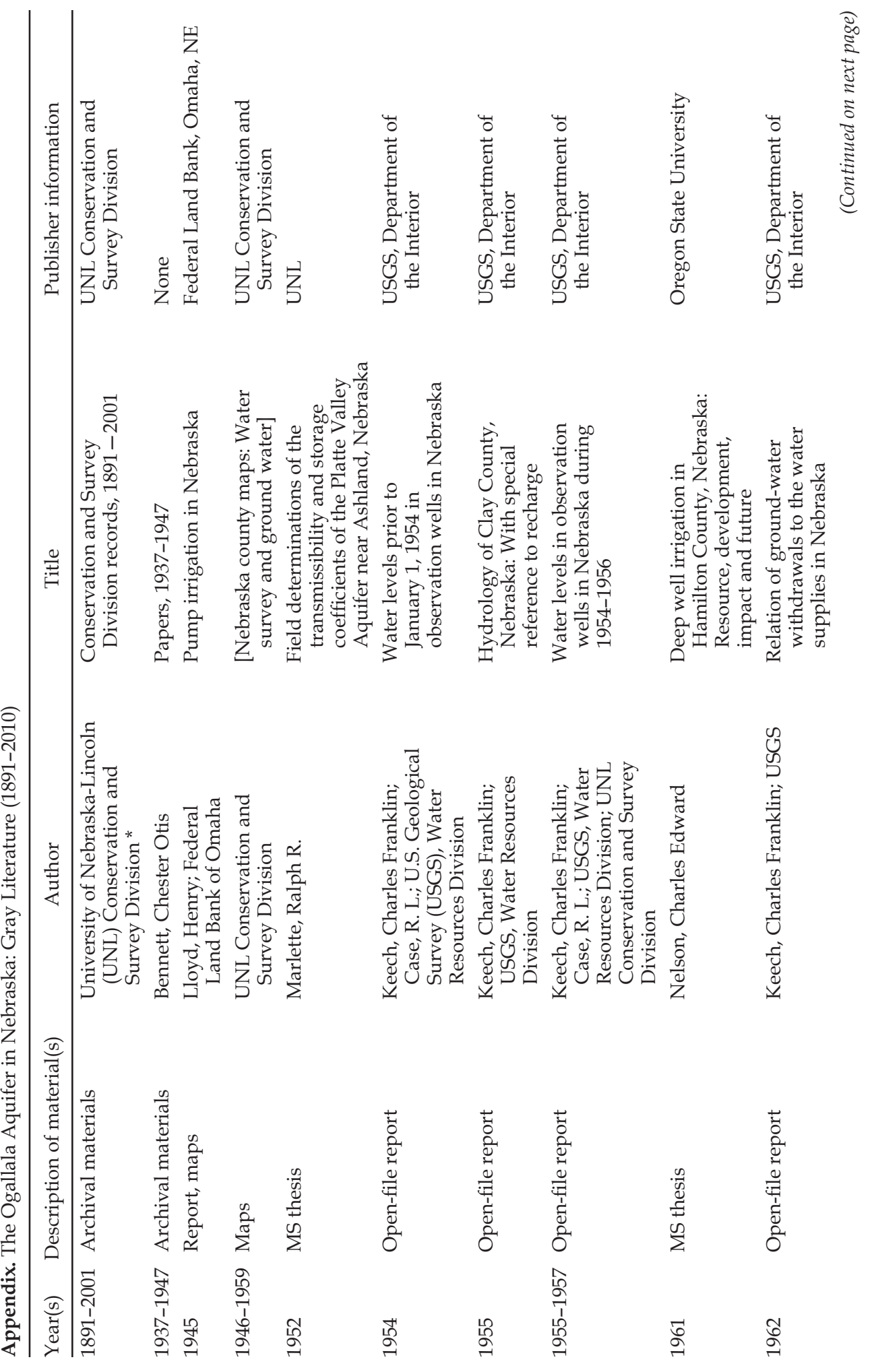




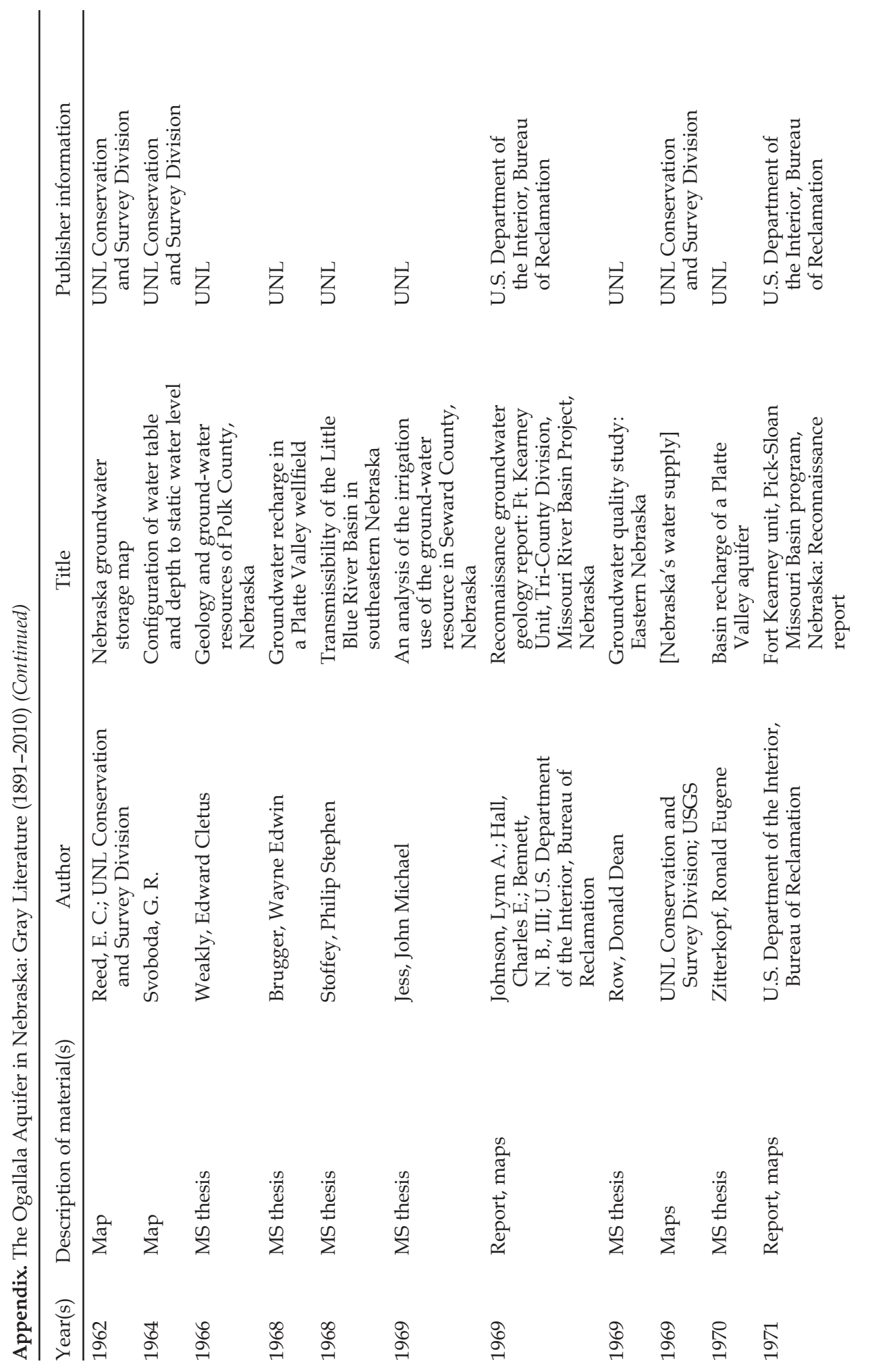



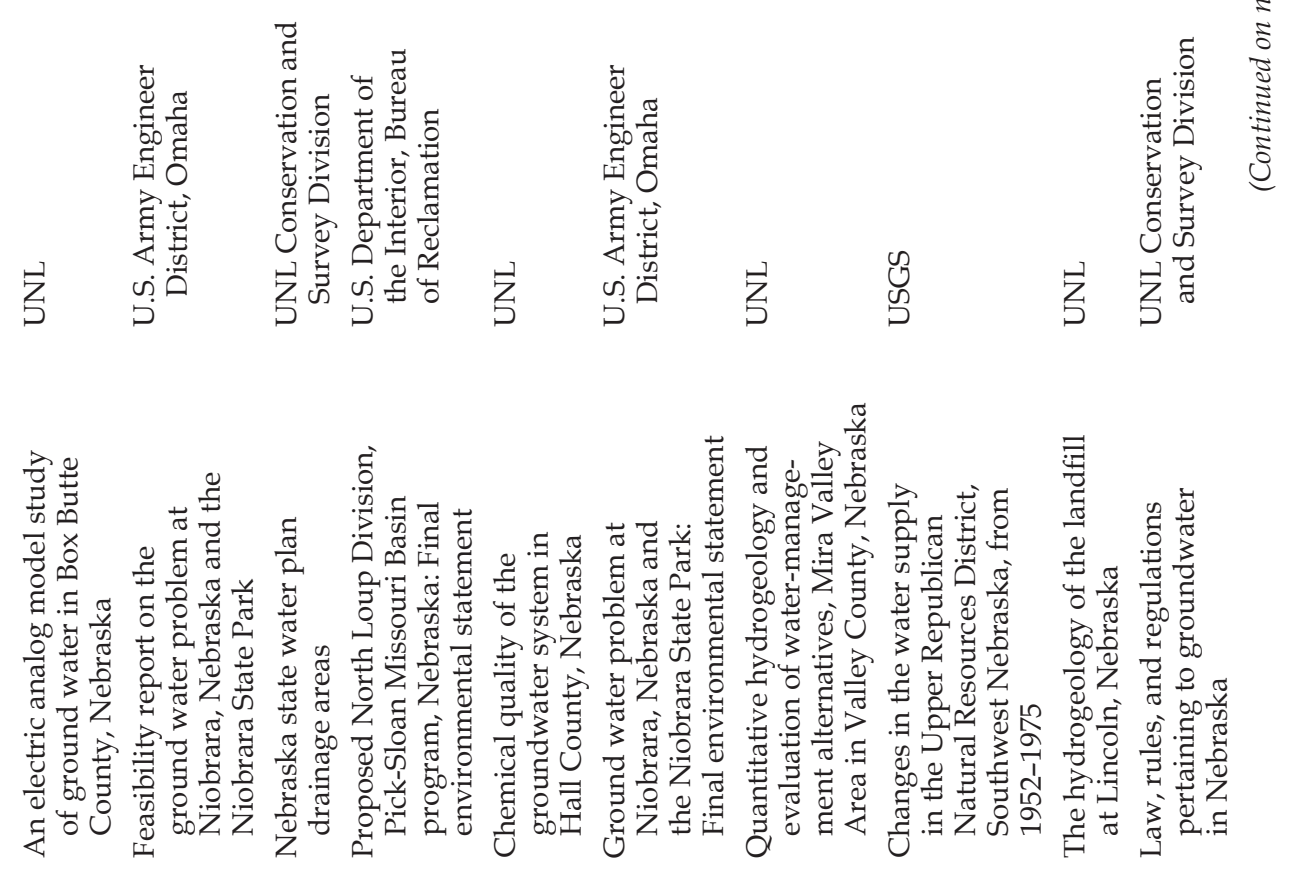

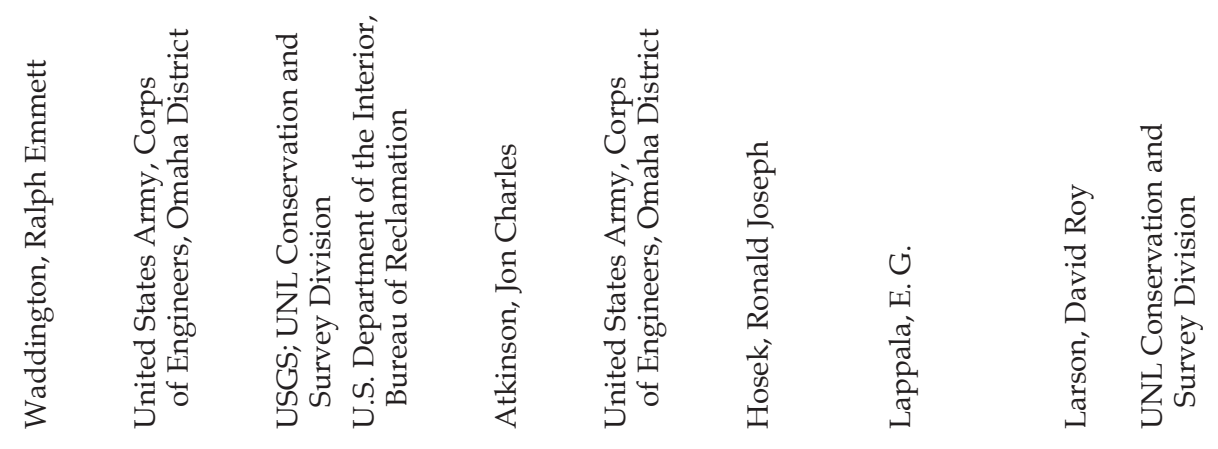

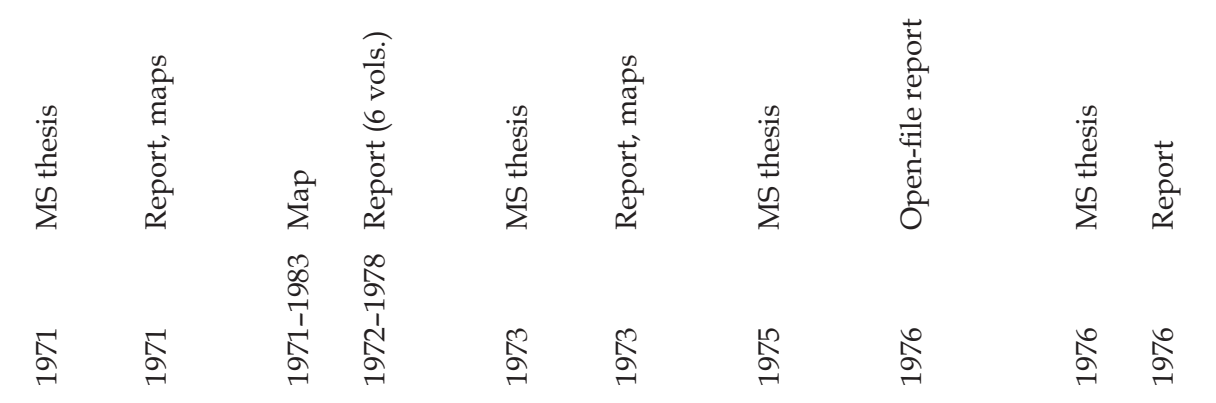




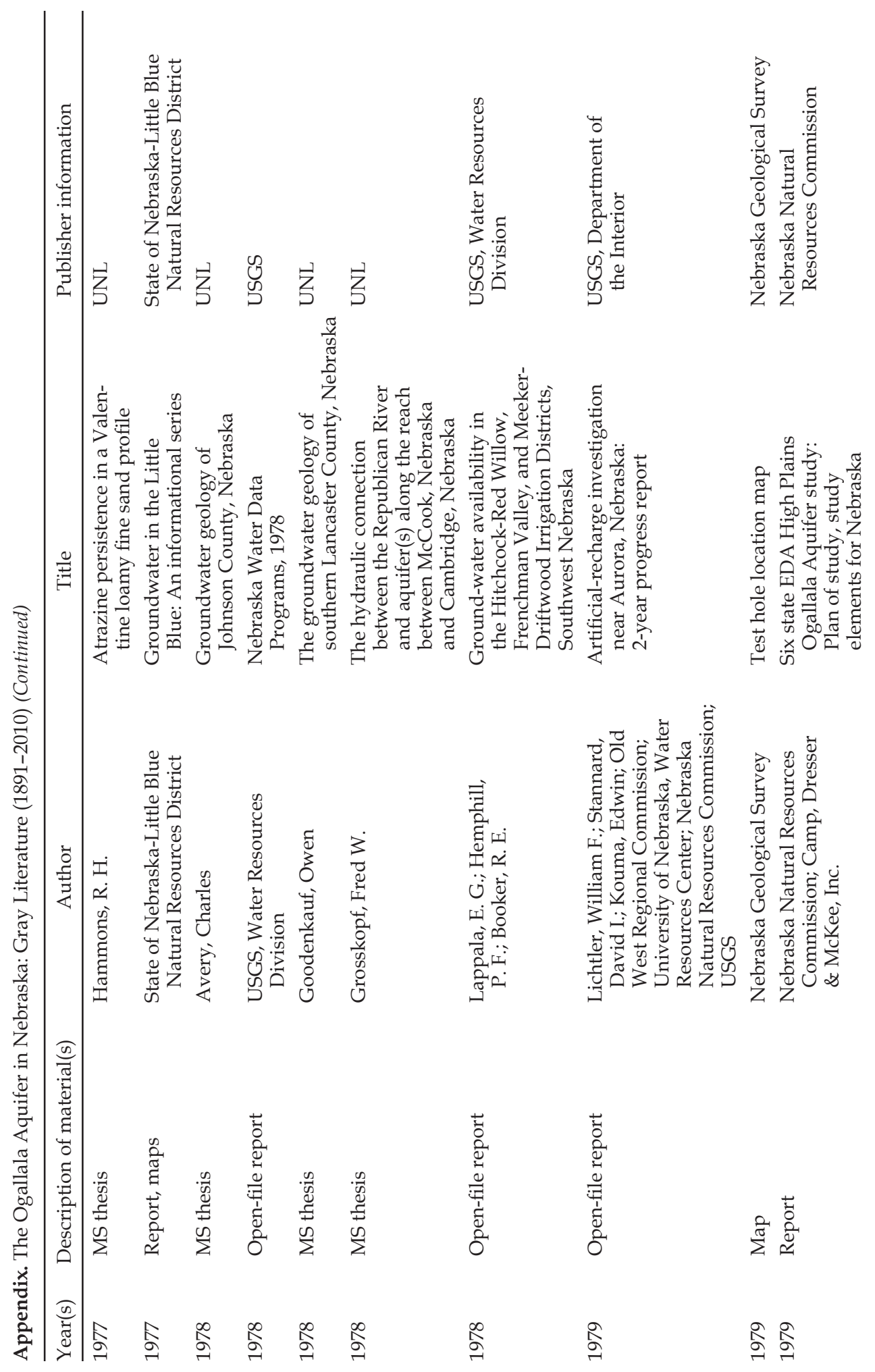



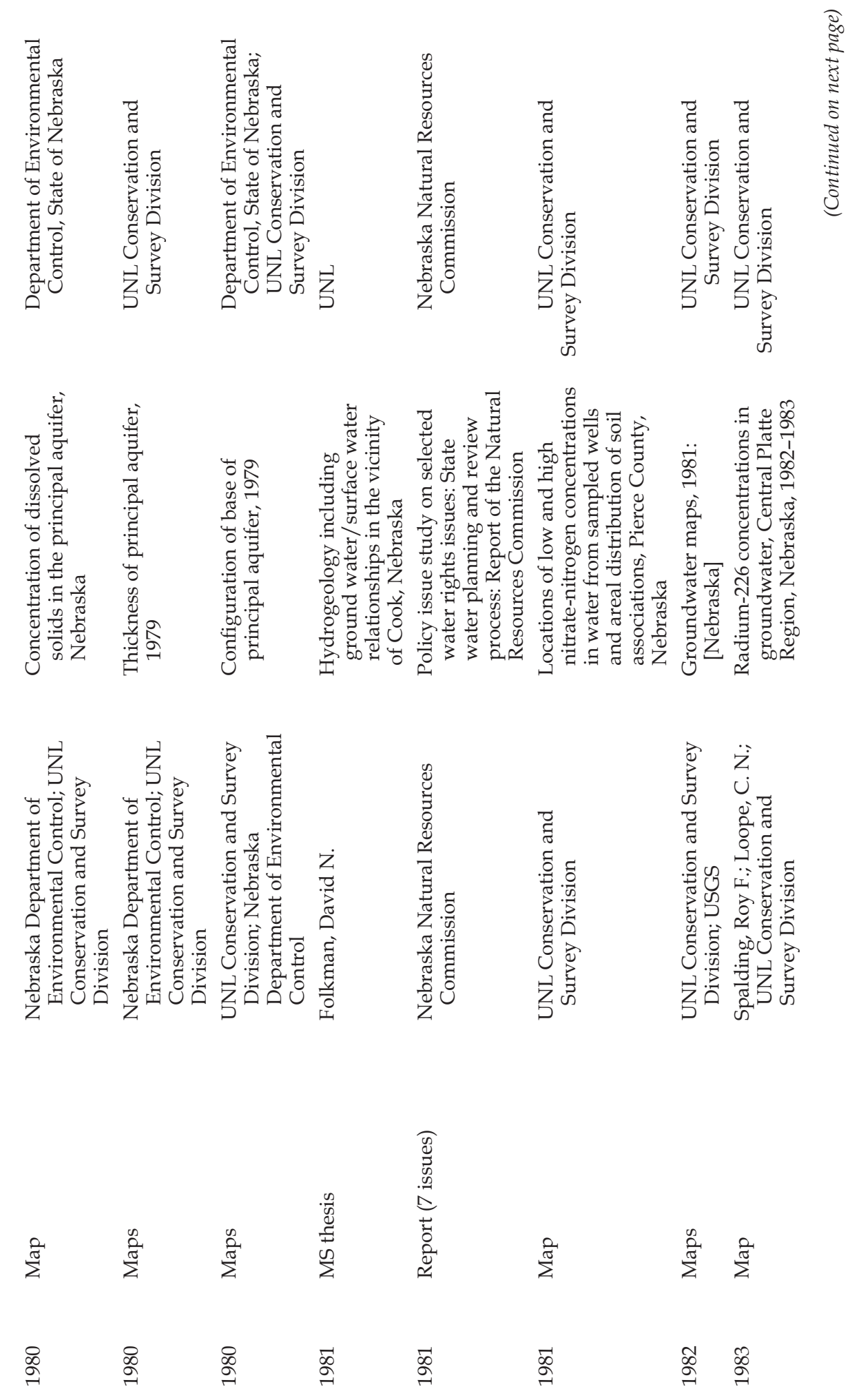


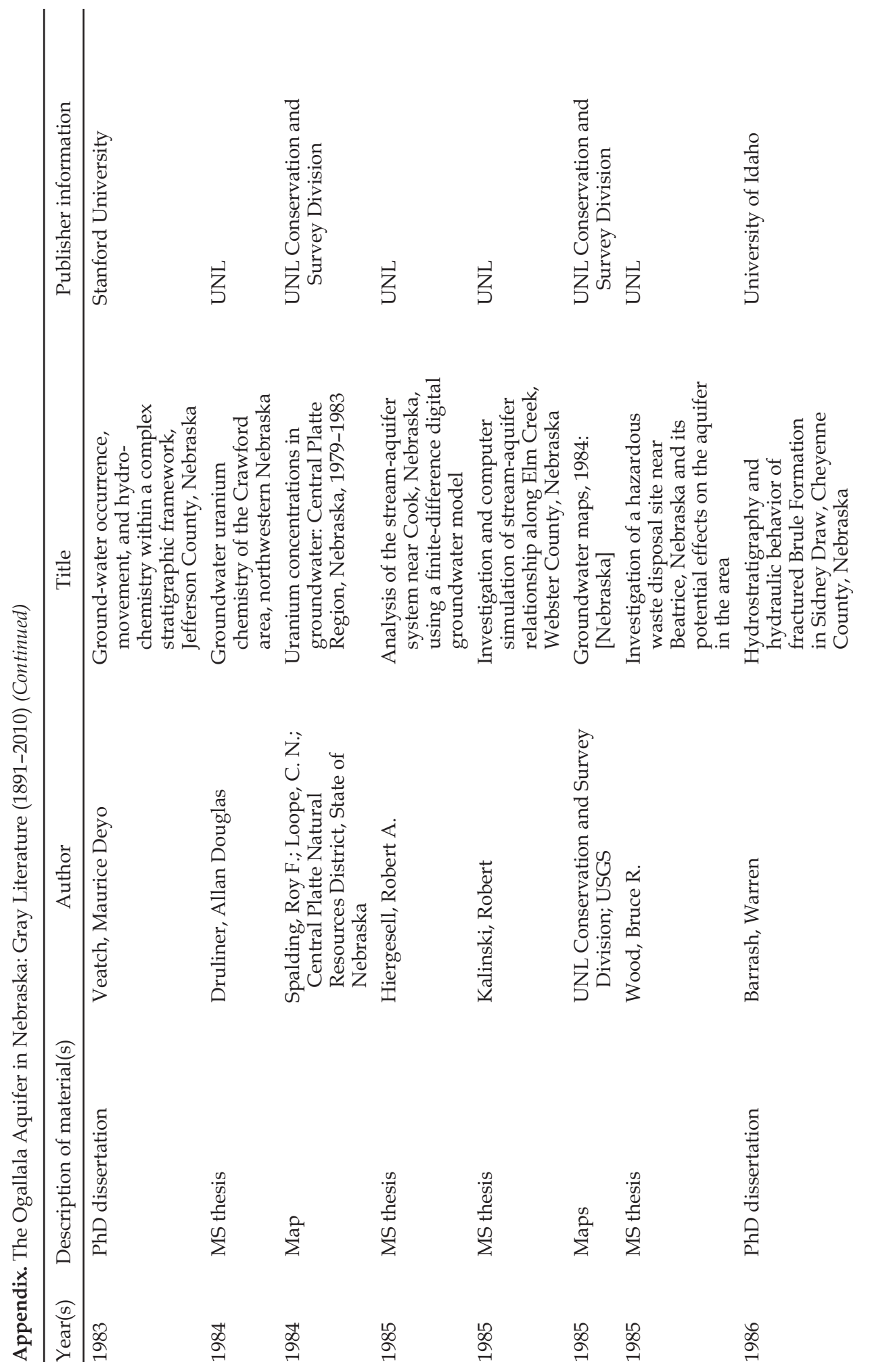



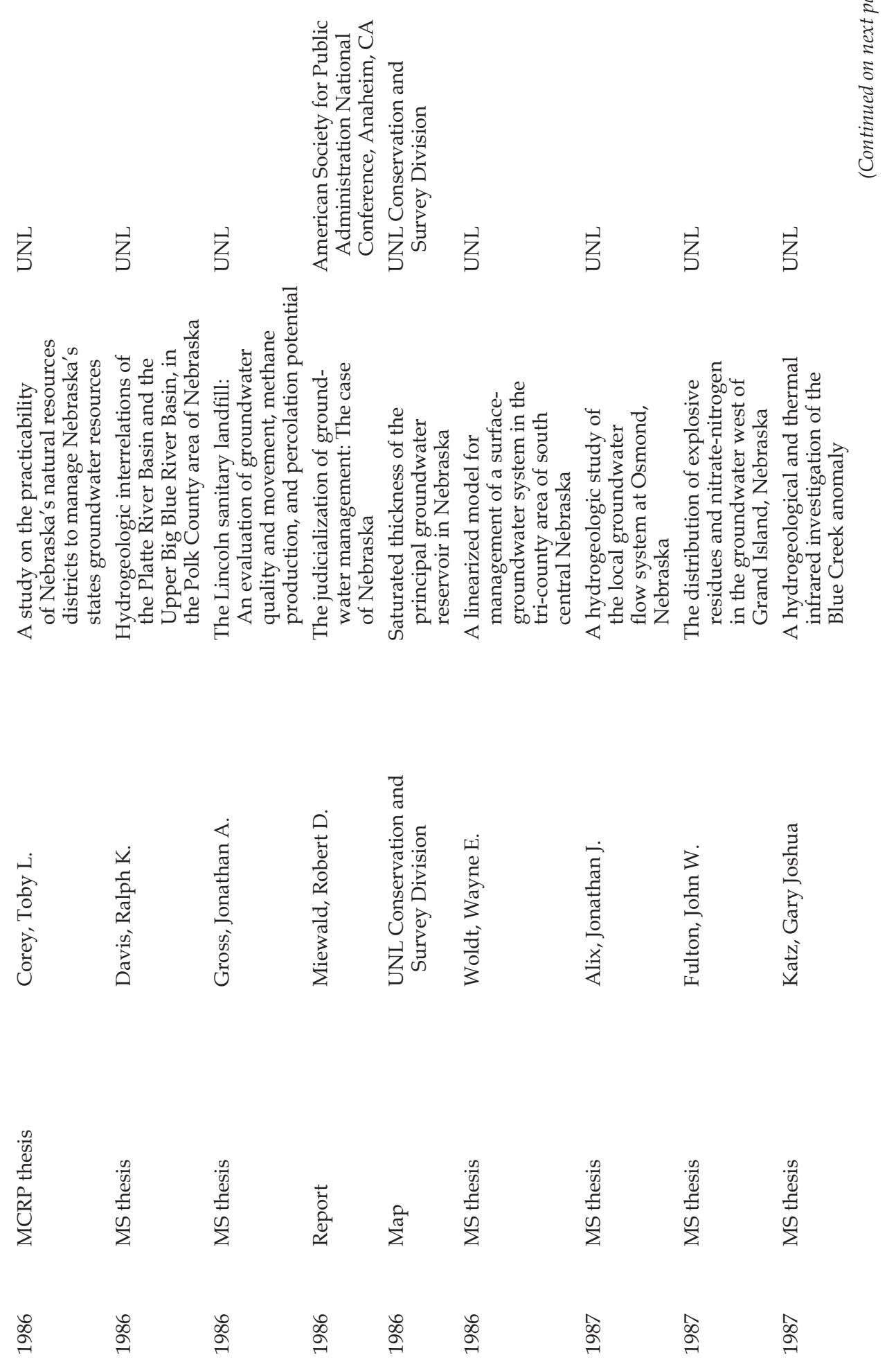


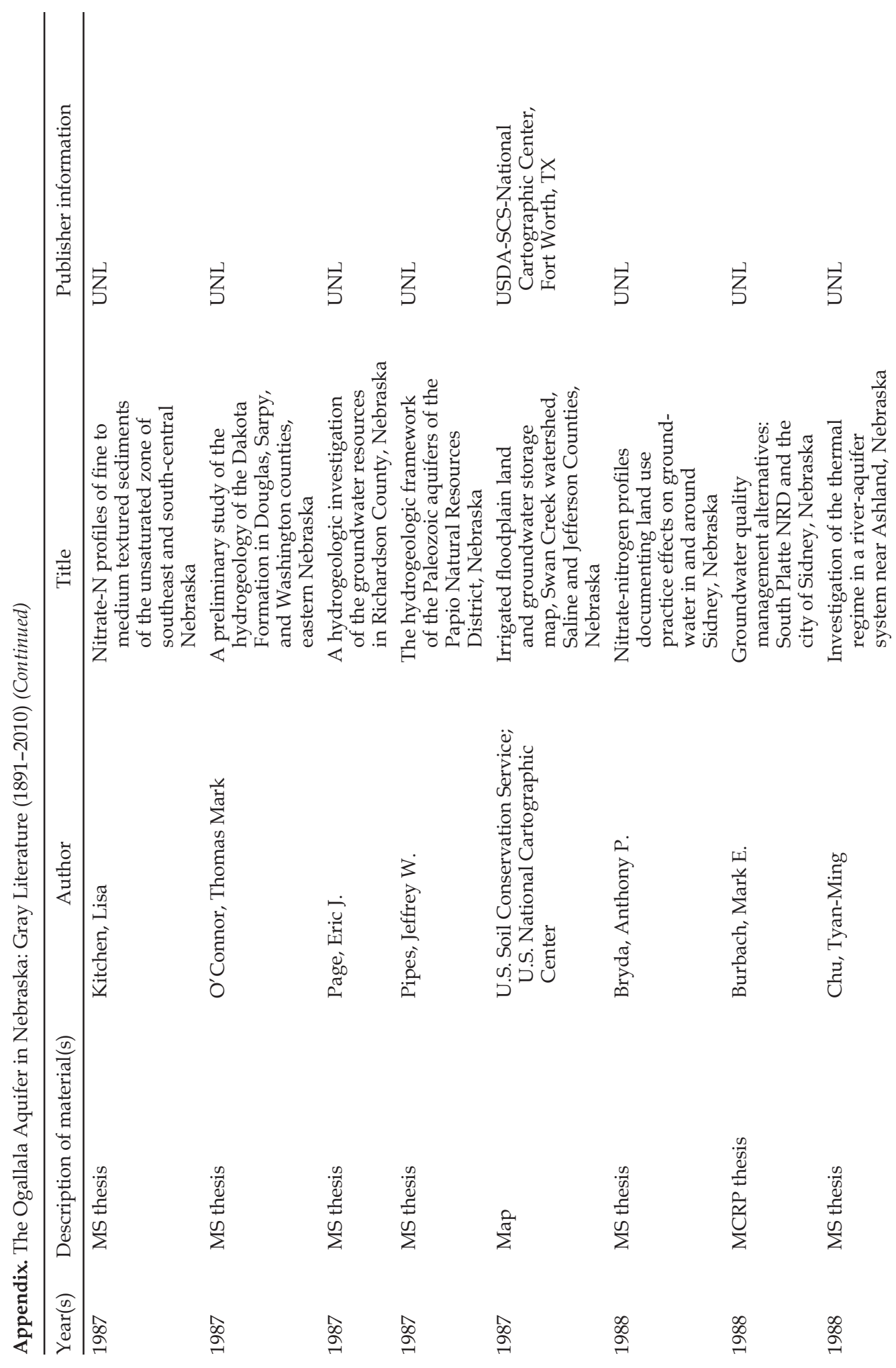



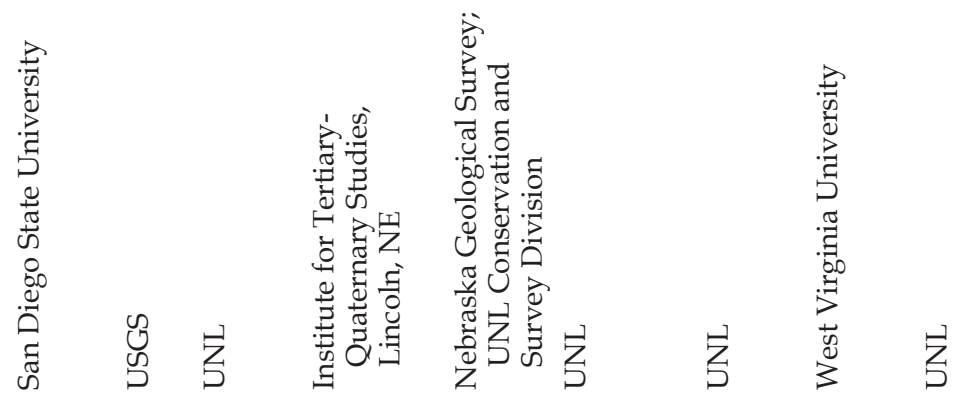

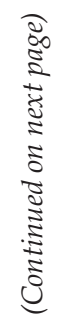
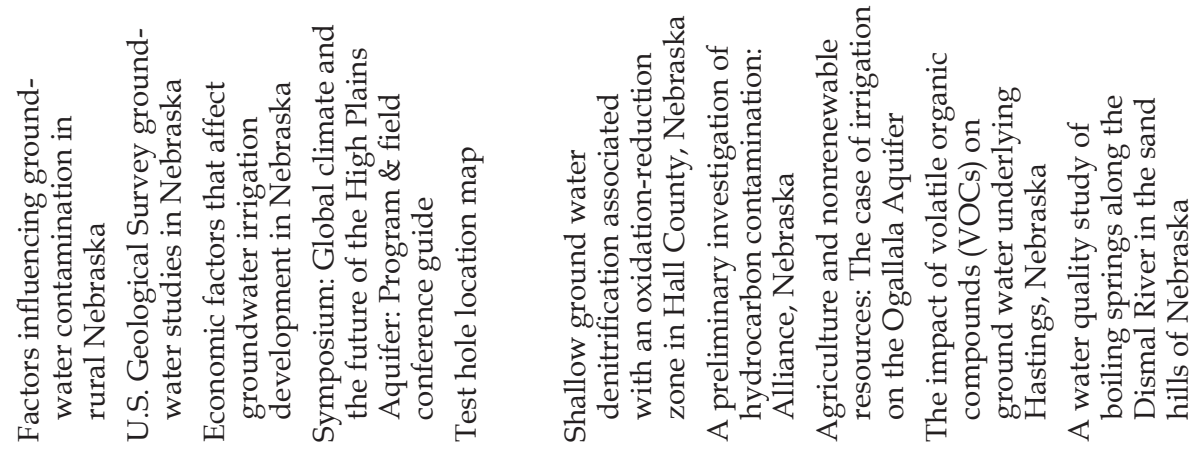

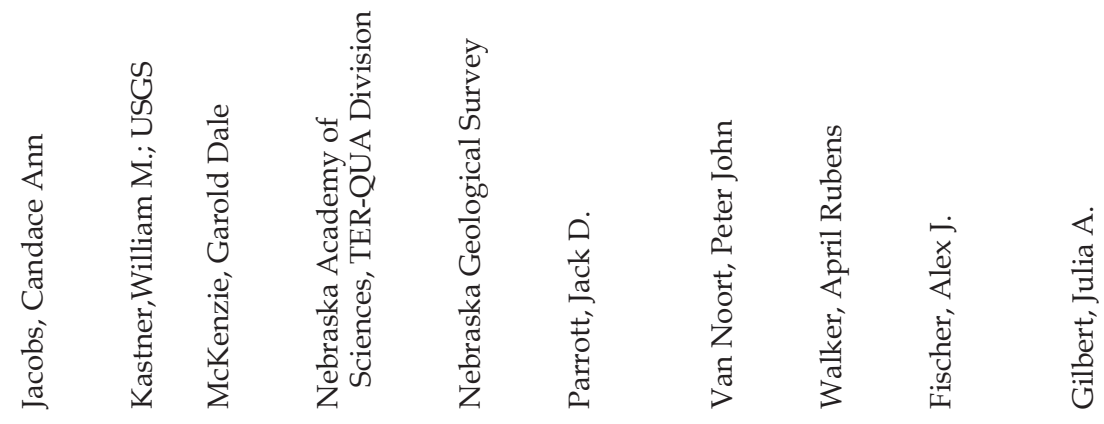

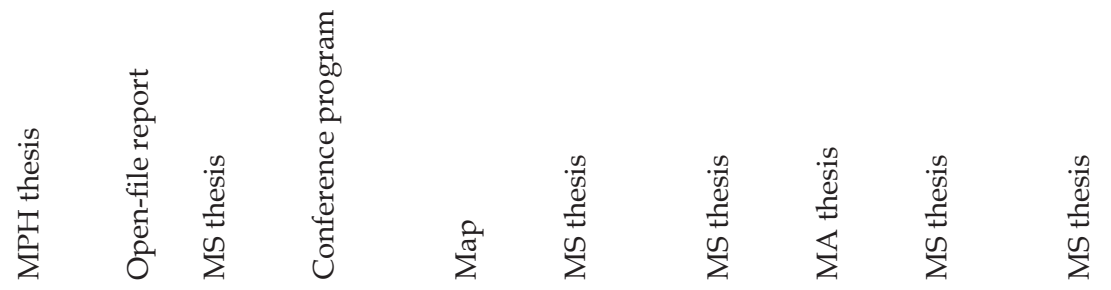

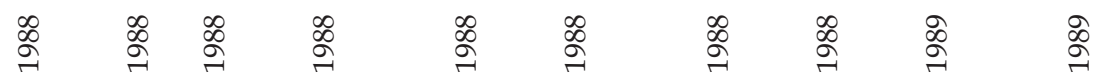




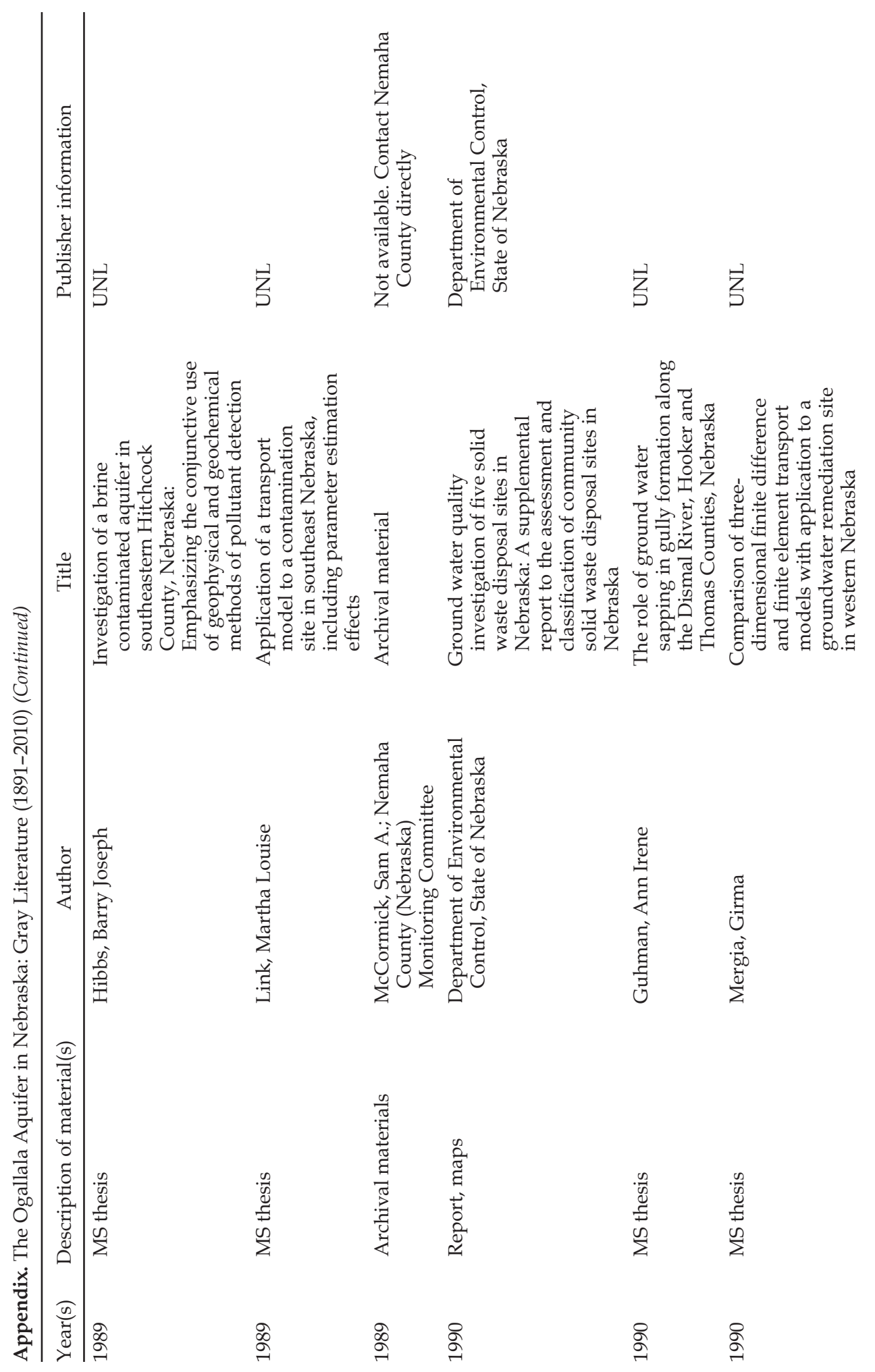



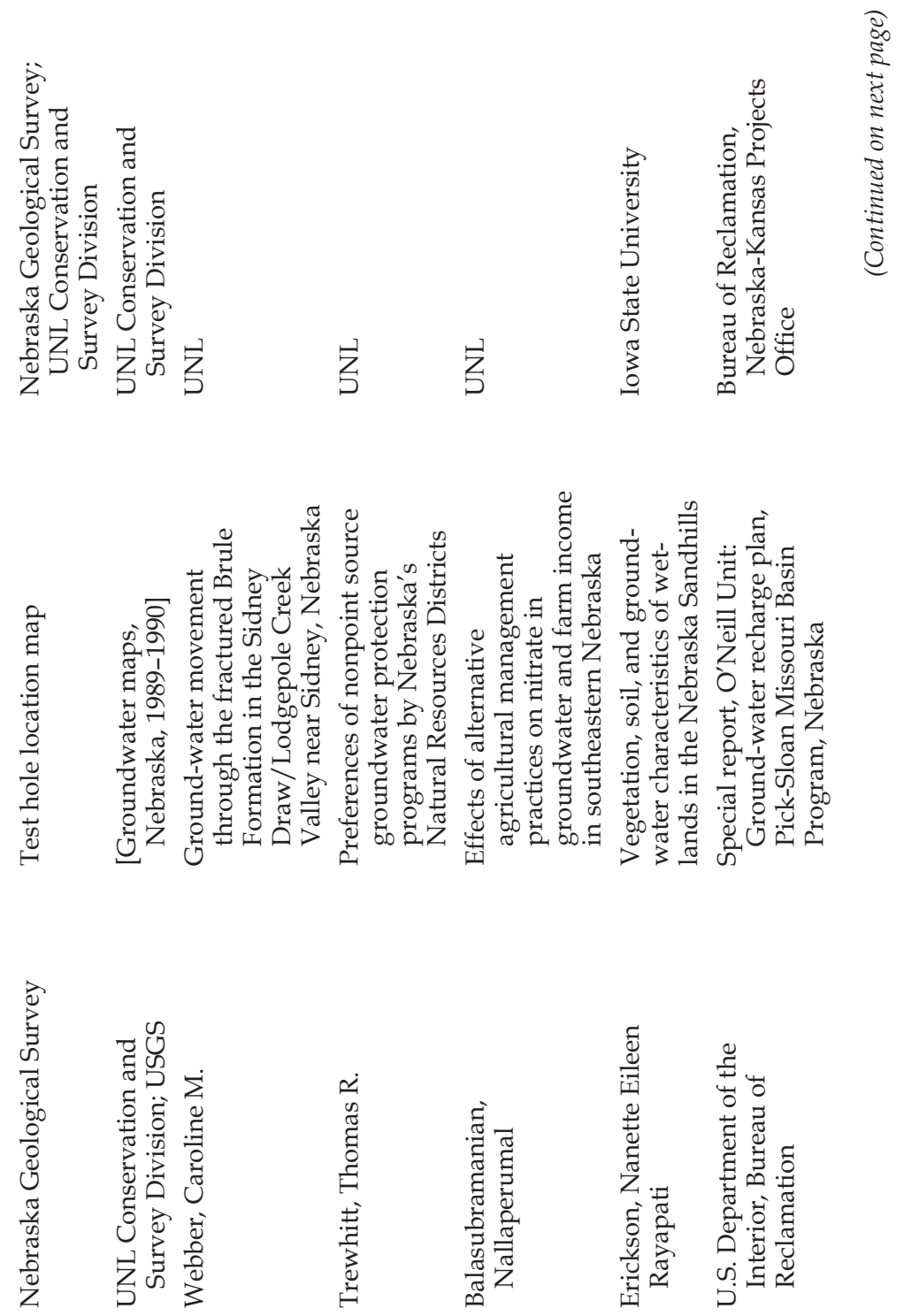

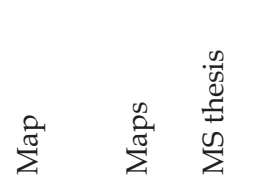

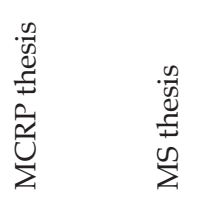

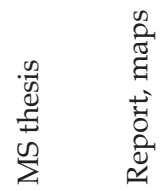
ஓ ஓ ஓ
๙ू
๙ू 


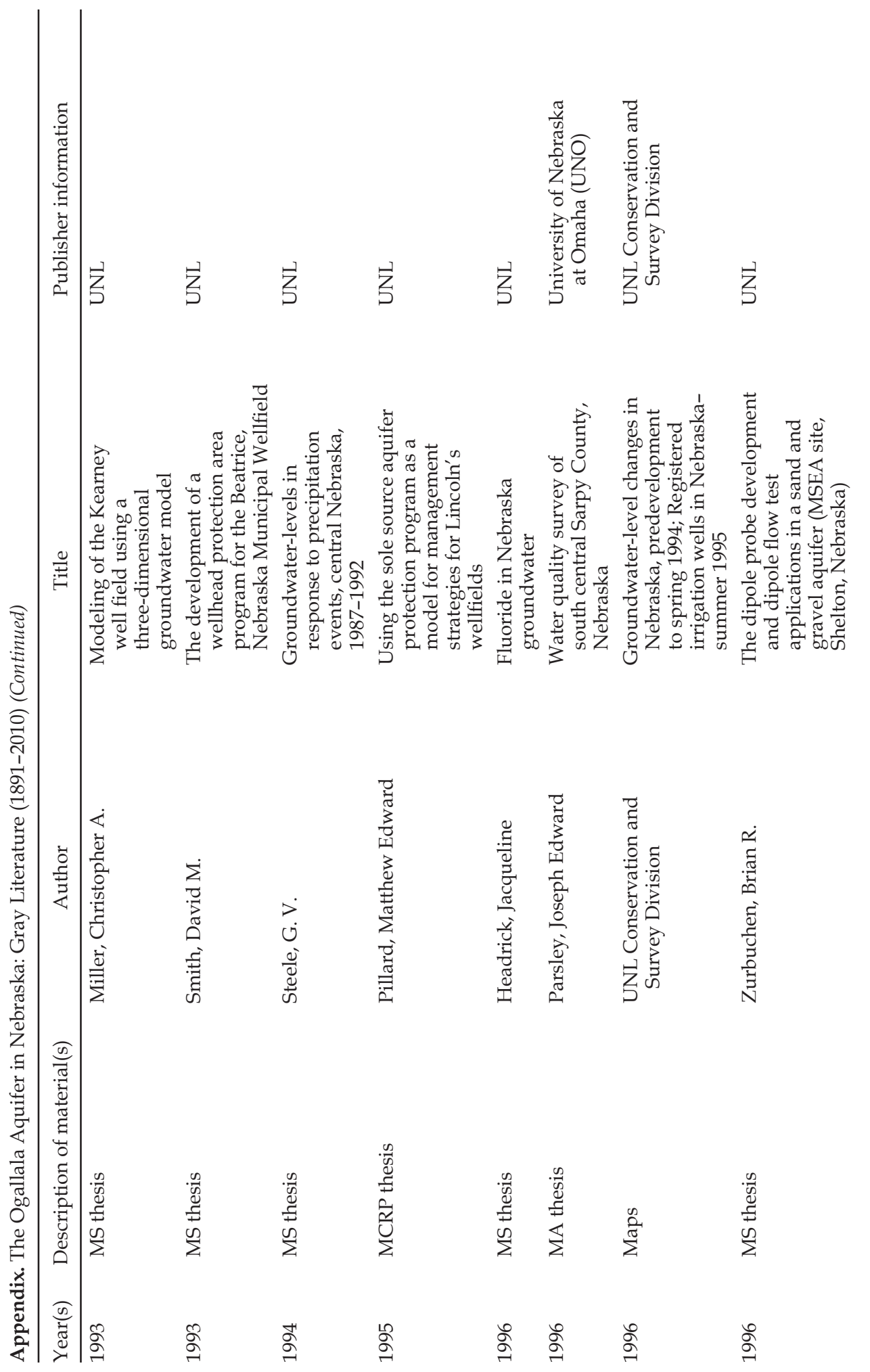



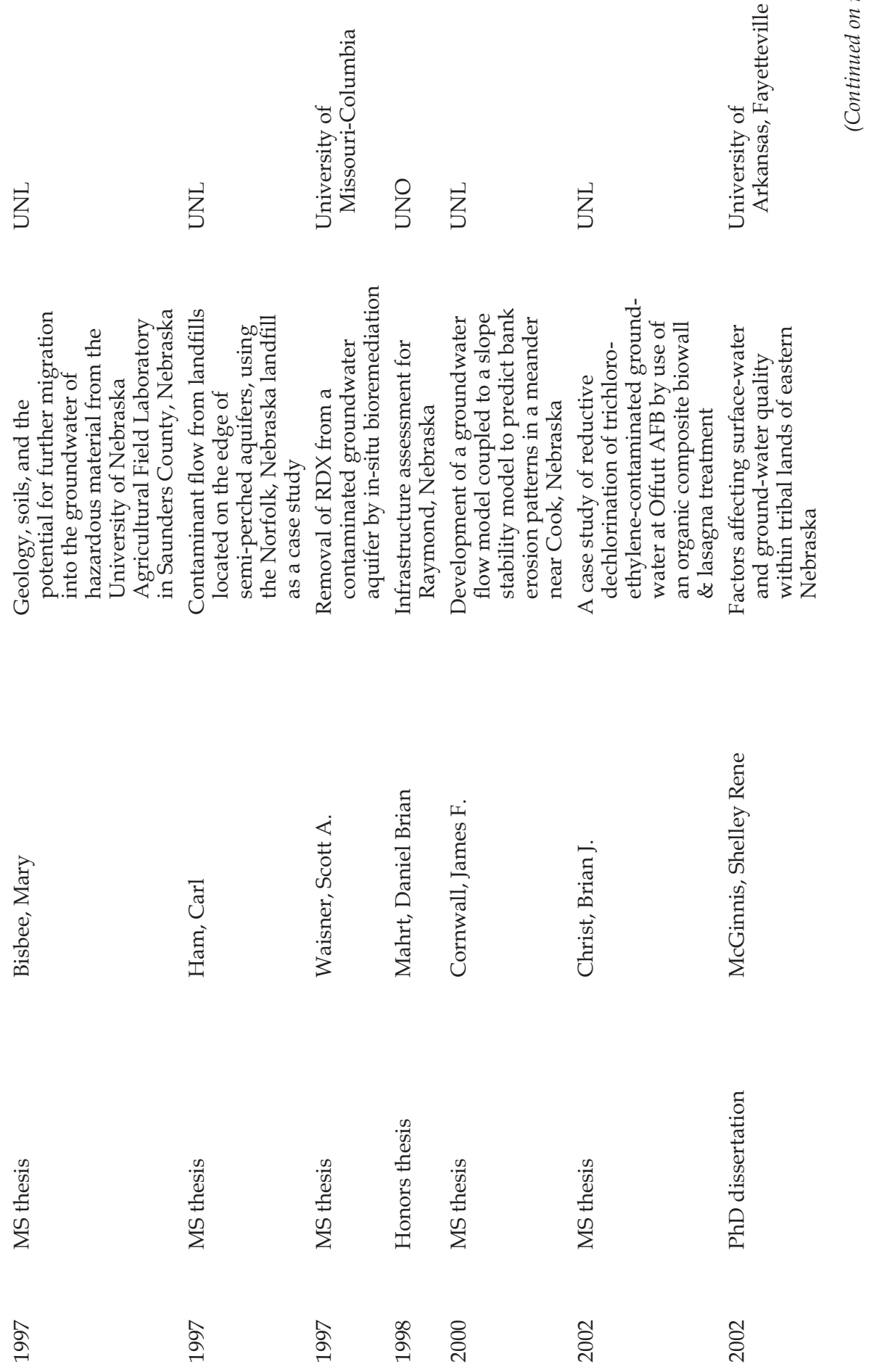


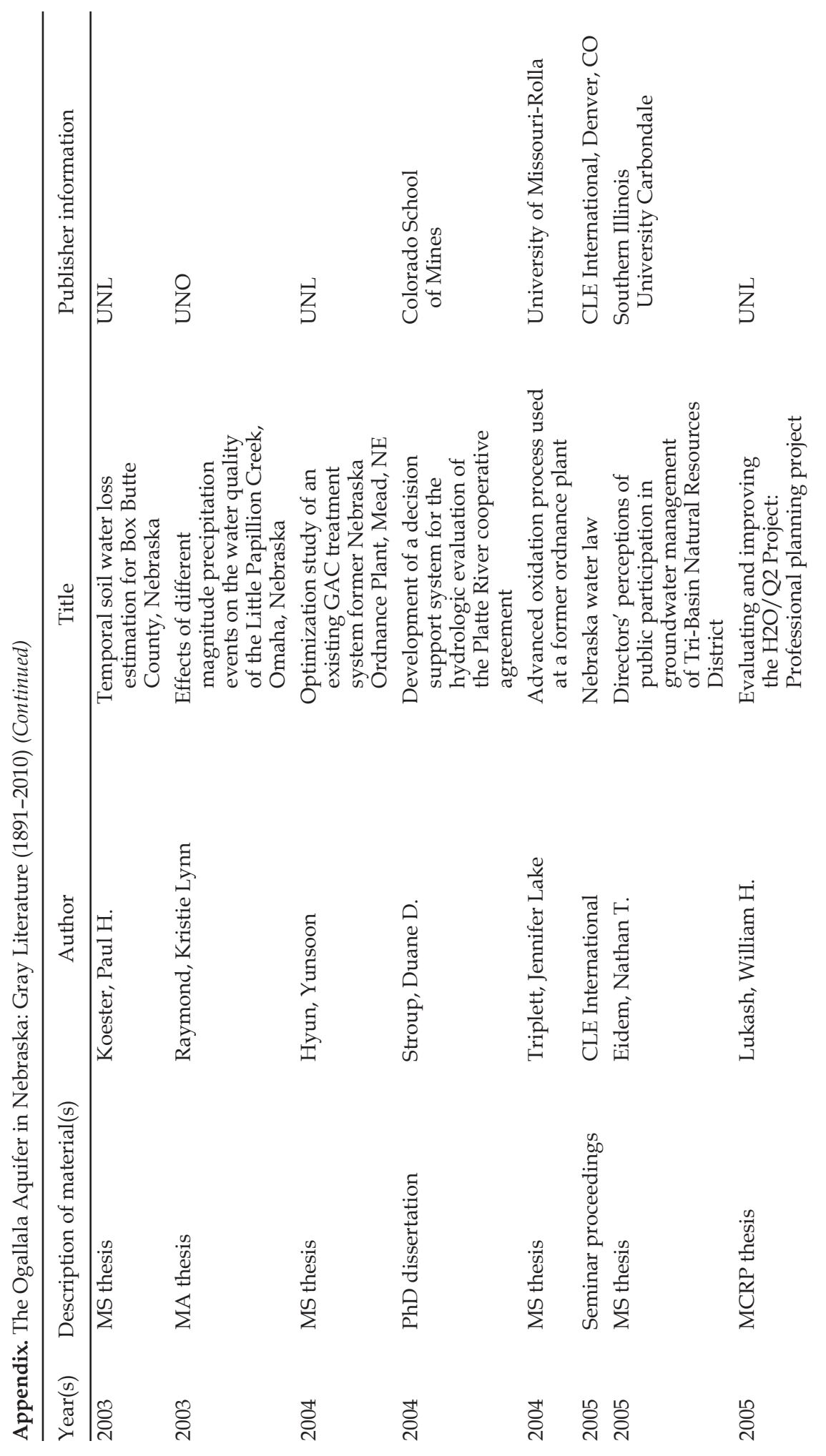



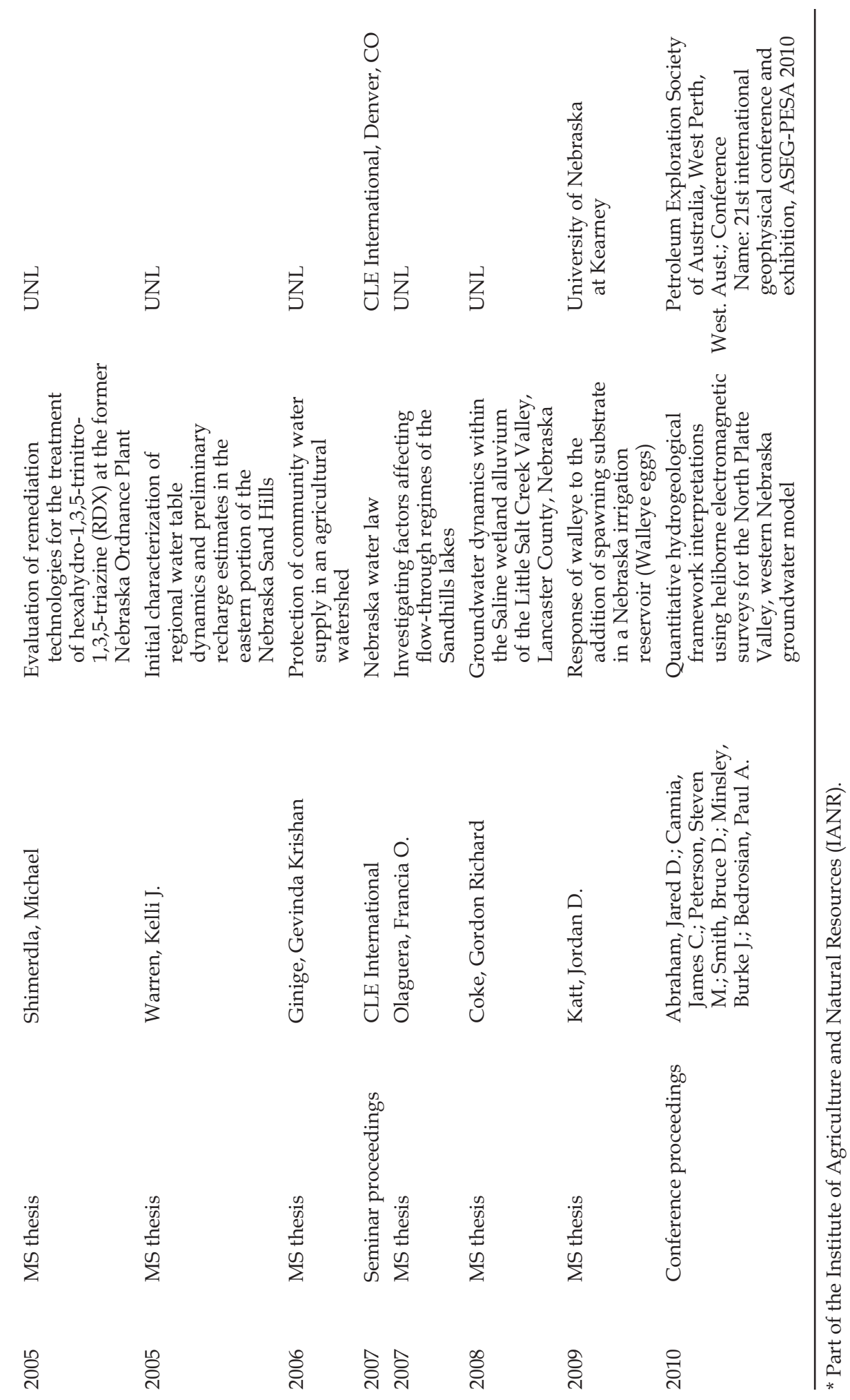